\title{
Therapeutic efficacy of ivermectin, fenbendazole and albendazole against naturally occuring gastrointestinal nematodiasis infection in Black Bengal Goat of Bangladesh
}

\author{
*Md. Aktaruzzaman ${ }^{1,2}$, Md. Mirazul Islam ${ }^{1}$, Zahurin Mohamed ${ }^{1}$, Md. Siddiqul Islam², Md. Matiar Rahman Howlader ${ }^{3}$ \\ ${ }^{1}$ Pharmacogenomics Lab, Department of Pharmacology, Faculty of Medicine, University of Malaya, 50603 Kuala Lumpur, Malaysia \\ ${ }^{2}$ Department of Pharmacology and Toxicology, Faculty of Veterinary and Animal Science, Sylhet Agricultural University, Sylhet-3100, Bangladesh \\ ${ }^{3}$ Department of Physiology, Faculty of Veterinary and Animal Science, Sylhet Agricultural University, Sylhet-3100, Bangladesh \\ *Corresponding author E-mail: drmazaman84sau@gmail.com
}

\begin{abstract}
This study aimed to evaluate the efficacy of ivermectin, fenbendazole and albendazole against gastrointestinal nematodes in naturally infected goats of government goat development farm, Sylhet, Bangladesh. The study included 50 black Bengal breed of which 30 were naturally infected and randomly selected 20 on the basis of their weight and egg count. Twenty black Bengal goats of 13-15 month old irrespective of sex infested with gastrointestinal nematodes were selected for this experiment and randomly divided into four equal groups (group A, B, C and D) where each group consisted of 5 goats and goats of group D were kept as control group. One injectable ivermectin ( $200 \mu \mathrm{gkg}-1$ body weight, S/C) preparations (Techno Drugs, Limited, Bangladesh) and two solid fenbendazole, albendazole (7.5 mgkg-1 body weight, orally) preparations (Techno Drugs, Limited and Square Pharmaceuticals Ltd, Bangladesh) were used for positive control of gastrointestinal nematodes as group A, B and C. Goats of group D was kept as control without giving any treatment. Before trials (day 0), total egg count, blood samples and initial body weight were recorded. During the study period the fecal and blood samples were collected directly from rectum and examined on $7^{\text {th }}, 14^{\text {th }}, 21^{\text {st }}$ and $28^{\text {th }}$ day using McMaster fecal egg counting method. Body weight was recorded on day 28 following the treatments. The therapeutic efficacy was evaluated through determination of parasitic prevalence, body weight gain/loss and hematological findings. Pre and post-treatment EPG (eggs per gram) values were recorded, and efficacies compared. The results showed that the efficacy of ivermectin was $100 \%$, followed by fenbendazole $95.33 \%$ and albendazole $90.11 \%$. The observed differences in efficacy between these three brands of anthelmintics were most likely due to variations either in quality or the administered doses. The body weight of the treated animals was slightly increased, which were significant $(\mathrm{p}<0.05)$. After treatment with ivermectin, fenbendazole and albendazole, Total Erythrocyte Count (TEC), Hemoglobin (Hb) content and Packed Cell Volume (PCV) were increased significantly $(p<0.01$ and $p>0.05)$ in goats but Erythrocyte Sedimentation Rate (ESR) and Total Leukocyte Count (TLC) were decreased significantly $(\mathrm{p}<0.05$ and $\mathrm{p}>0.01)$ in all treated goat and body weight was increased significantly $(p<0.01)$ on day 28. The farm management practices along with results of the present study revealed the efficacy of multiple anthelmintics against gastrointestinal nematodiasis in goat. Additional detailed studies are required to clarify the current status of the efficacy of the anthelmintics widely used in different agro ecologies, animal species and livestock management systems in Bangladesh.
\end{abstract}

Keywords: Comparative efficacy; gastrointestinal nematodes; goat; Sylhet.

\section{Introduction}

Goats are reared mainly in the rural areas of Bangladesh. The climatic condition of Bangladesh is favorable to the ecological conditions suitable for parasites of which the helminth parasite predominates. The gastrointestinal nematodiasis causes great economic losses in the form of mortality, stunted growth, weight loss, decreased milk and meat production and market value of the living animals Islam (1985). The incidence of gastrointestinal nematodes in goats and sheep in Mymensingh was reported by Haq and Shaikh (1968). Modern anthelmintics such as Benzimidazoles like albendazole and fenbendazole are widely used in Bangladesh and very recently ivermectin is being used sporadically. Most of the anthelmintics used in this country are being imported and there is no data available about efficacy, safety, toxicity and dose regime in livestock in Bangladesh. Goats play a vital role within the subsistence economy of small holders in Bangladesh. Agriculture is the economic backbone of Bangladesh and approximately $80 \%$ people depend on it directly or indirectly for their subsistence. The livestock is an important sub-sector which is considered to be the backbone of agriculture in Bangladesh BBS (1998). Among livestock, the population in Bangladesh is currently estimated to comprise 20.75 million goats DLS (2007). Gastrointestinal parasites pose the greatest challenge to goat health and production in humid areas Perry et al. (2002) and Sahlu et al. (2009). The prevalence of anthelmintics resistance is a serious constraint to goat production globally Howell et al. (2008); Jackson and Coop (2000); Kaplan et al. (2004). The use of sustainable, integrated parasite control systems, using scientifically proven non chemical methods and limited use of drugs are being considered to ensure animal health and food-safety Waller (2006).The The present investigation was aimed to evaluate the comparative efficacy of modern anthelmintics Almex-Vet (Albendazole), Peraclear (Fenbendazole) and Vermic injection (Ivermectin) against gastrointestinal nematodiasis in goats based on EPG count and their effects on hematological parameters like TEC, Hb, PCV, ESR, TLC and body weight gain/loss were included in this investigation. 


\section{Materials and methods}

The experiment was conducted in the Department of Pharmacology and Toxicology, Sylhet Agricultural University, Sylhet and Sylhet Government Goat Development farm, Sylhet. Bangladesh was selected in this study. The research was carried out during the period of January to June, 2013. The following procedures were adopted for performing the experiment. Twenty black Bengal goats of 13-15 months old are selected within the randomly sampling goats which were severely infected with gastrointestinal nematodiasis irrespective of the species of parasites involved. These twenty goats were randomly divided among four groups each comprising of five goats and marked as A, B, C and D.

Blood and fecal samples were collected from each black Bengal goat and after prescribing a proper identification tag it and were immediately brought to the Pharmacology and Toxicology Laboratory, Sylhet, Bangladesh for fecal examination. Weekly EPG count was done on day $7^{\text {th }}, 14^{\text {th }}, 21^{\text {st }}$ and $28^{\text {th }}$ post treatment by McMaster egg counting technique. McMaster fecal egg count method described by Gordong and Whitlock (1939) was used With sterile syringe and needle maintaining aseptic condition, 5 $\mathrm{ml}$ of blood sample was collected from jugular vein of each black Bengal goat and kept in vials containing anticoagulant (sodiumEDTA) and this was done on day of $0,7^{\text {th }}, 14^{\text {th }}, 21^{\text {st }}$ and $28^{\text {th }}$ during experimental period. The hematological parameters were examined at the laboratory of the Department of Pharmacology and Toxicology, Sylhet, Bangladesh. Live weight gain of each group on recorded on day 0 and 28 using digital weight balance.

Goats of group A were treated with Vermic injection (Ivermectin $1 \%$, Techno Drugs, Ltd., Bangladesh) subcutaneously at the dose rate of $200 \mu \mathrm{gkg}-1$ body weight, group B was treated with tablet Peraclear (Fenbendazole, Techno Drugs, Ltd., Bangladesh) orally at the dose rate of $7.5 \mathrm{mgkg}-1$ body weight. Group $\mathrm{C}$ was treated with tablet Almex-Vet (Albendazole, Square Pharmaceuticals Ltd., Bangladesh) orally at the dose rate of $7.5 \mathrm{mgkg}-1$ body weight and goats of group D served as untreated control.

All the goats of treated and control groups were closely observed for 28 days after treatment. The fecal samples were collected from the treated and control groups of goats on $7^{\text {th }}, 14^{\text {th }}, 21^{\text {st }}$ and $28^{\text {th }}$ day of treatment to investigate the fecal egg count. The blood samples were collected from the treated and untreated control groups on the day ' 28 ' of treatment and hematological parameters, TEC, Hb, PCV, ESR and TLC were determined as per method by Coffin (1995). All the data were statistically analyzed by the computer using statistical package programmed MSTAT-C developed by Russel (1996) and following the standard methods by Snedecor and Cochran (1967). The eggs of parasites were identified on the basis of morphological characteristics as described by Soulsby (1986) and then counted.

\section{Results}

In this study the goats of group A were treated with Vermic injection (injectable Ivermectin) at the dose rate of $200 \mu \mathrm{gkg}-1$ body weight subcutaneously and the rate of reduction of EPG was $100 \%$ on the $28^{\text {th }}$ day. This result is in agreement with the earlier researchers. The goats of group B were treated with tablet Peraclear (Fenbendazole) at the dose rate of $7.5 \mathrm{mgkg}-1$ body weight orally and the rate of reduction on EPG on the $28^{\text {th }}$ day was $95.33 \%$. This result was found by earlier workers Beck et al. (1971); Sharma and Jagadish (1991); Prodhan et al. (1993); Thejeomooethy et al. (1995); Vesconcelos et al. (1995) and Williams and Broussared (1995). The goats of group C were treated with tablet Almex-Vet (Albendazole) at the dose rate of $7.5 \mathrm{mgkg}-1$ body weight orally and the rate of reduction in EPG on the $28^{\mathrm{th}}$ day was $90.11 \%$ (Table 1).

Guha et al. (1996) stated that Almex-Vet at the dose rate of 3.5 mgkg-1 body weight was $100 \%$ effective against gastrointestinal nematodiasis in naturally infected goats. In untreated naturally parasitized control group D the mean EPG was $911.00 \pm 7.29$ at ' 0 ' day and at $7^{\text {th }}, 14^{\text {th }}, 21^{\text {st }}$ and $28^{\text {th }}$ days were $930.00 \pm 9.13$, $950.00 \pm 8.98,970.00 \pm 8.98$ and $995.00 \pm 5.40$ and the rate of infection was increased. During the study of hematological parameters it was found that after treatment with Vermic (injectable formulation), Peraclear (Fenbendazole) and Almex-Vet (Albendazole) TEC, Hb and PCV were significantly ( $p<0.01$ and $p>0.05)$ increased and on the other hand, ESR was decreased up to $100 \%$ in treated groups (Table 2).

Table 1: Effects of different anthelmintics on egg count (EPG) in goats

\begin{tabular}{|c|c|c|c|c|c|c|c|}
\hline \multirow[b]{2}{*}{ Groups } & \multirow[b]{2}{*}{ Treatment } & \multirow{2}{*}{$\begin{array}{l}\text { Pre-treatment } \\
\text { Day } 0\end{array}$} & \multicolumn{5}{|c|}{ Post-treatment } \\
\hline & & & Day 7 & Day 14 & Day 21 & Day 28 & $\begin{array}{l}\% \text { Reduction at day } \\
\text { " } 28 "\end{array}$ \\
\hline GA & Inj. Vermic® & $\begin{array}{l}815.00 \\
\pm \\
10.22\end{array}$ & 0 & 0 & 0 & 0 & 100 \\
\hline GB & Peraclear ${ }^{\circledR}$ & $\begin{array}{l}750.00 \\
\pm \\
12.09\end{array}$ & $\begin{array}{l}140.00 \\
\pm \\
4.25 * *\end{array}$ & $\begin{array}{l}100.00 \\
\pm \\
2.51 * *\end{array}$ & $\begin{array}{l}60.00 \\
\pm \\
5.61 * *\end{array}$ & $\begin{array}{l}35.00 \\
\pm \\
3.15^{* *}\end{array}$ & 95.33 \\
\hline GC & Almex- vet ${ }^{\circledR}$ & $\begin{array}{l}708.00 \\
\pm \\
7.50\end{array}$ & $\begin{array}{l}171.00 \\
\pm \\
5.41^{* *}\end{array}$ & $\begin{array}{l}133.00 \\
\pm \\
6.63 * *\end{array}$ & $\begin{array}{l}106.00 \\
\pm \\
5.46 * *\end{array}$ & $\begin{array}{l}70.00 \\
\pm \\
5.32 * *\end{array}$ & 90.11 \\
\hline GD & Control group & $\begin{array}{l}911.00 \\
\pm \\
7.29 \\
\end{array}$ & $\begin{array}{l}930.00 \\
\pm \\
9.13 * *\end{array}$ & $\begin{array}{l}950.00 \\
\pm \\
8.98 * *\end{array}$ & $\begin{array}{l}970.00 \\
\pm \\
8.98 * *\end{array}$ & $\begin{array}{l}995.00 \\
\pm \\
5.40 * *\end{array}$ & - \\
\hline
\end{tabular}

** = Significant at 1 percent level $(\mathrm{p}<0.01)$

Table 2: Hematological findings of control and study groups at day 28 post treatment

\begin{tabular}{|c|c|c|c|c|c|c|c|c|c|c|c|}
\hline \multirow{3}{*}{ Groups } & \multirow{3}{*}{ Treatment } & \multicolumn{5}{|c|}{ Pre-treatment } & \multicolumn{5}{|c|}{ Post-treatment } \\
\hline & & \multicolumn{5}{|c|}{ Day 0} & \multicolumn{5}{|c|}{ Day 28} \\
\hline & & TEC & $\mathrm{Hb}$ & PCV & ESR & TLC & TEC & $\mathrm{Hb}$ & PCV & ESR & TLC \\
\hline \multirow{4}{*}{ GA } & \multirow{3}{*}{ Inj. Vermic® } & 8.16 & 7.94 & 27.76 & 0.12 & 8.12 & 13.11 & 10.21 & 30.02 & & 7.92 \\
\hline & & \pm & \pm & \pm & \pm & \pm & \pm & \pm & & 0 & \pm \\
\hline & & 0.10 & 0.09 & 0.12 & 0.01 & 0.04 & $0.12 * *$ & $0.07 * *$ & $0.08^{*}$ & & $0.06 * *$ \\
\hline & \multirow{4}{*}{ Peraclear ${ }^{\circledR}$} & 8.18 & 8.33 & 28.07 & 0.10 & 8.12 & 12.27 & 10.06 & 30.16 & & 7.96 \\
\hline \multirow[t]{3}{*}{ GB } & & \pm & \pm & \pm & \pm & \pm & \pm & \pm & \pm & 0 & \pm \\
\hline & & 0.12 & 0.08 & 0.12 & 0.01 & 0.06 & $0.12 * *$ & $0.13^{* *}$ & $0.06^{*}$ & & $0.07 * *$ \\
\hline & & 8.25 & 8.34 & 28.00 & 0.11 & 8.24 & 12.11 & 10.16 & 29.32 & & 8.06 \\
\hline \multirow[t]{3}{*}{ GC } & \multirow[t]{3}{*}{ Almex-vet $\circledast$} & \pm & \pm & \pm & \pm & \pm & \pm & \pm & \pm & 0 & \pm \\
\hline & & 0.14 & 0.16 & 0.10 & 0.01 & 0.06 & $0.06 * *$ & $0.13^{* *}$ & $0.13^{*}$ & & $0.04 * *$ \\
\hline & & 8.20 & 8.91 & 27.96 & 0.11 & 7.29 & 7.48 & 7.93 & 26.90 & 0.19 & 8.22 \\
\hline \multirow[t]{2}{*}{ GD } & \multirow[t]{2}{*}{ Control group } & \pm & \pm & \pm & \pm & \pm & \pm & \pm & \pm & \pm & \pm \\
\hline & & 0.12 & 0.15 & 0.08 & 0.01 & 0.12 & $0.15 * *$ & $0.06^{* *}$ & $0.10 *$ & 0.01 & $0.07^{* * *}$ \\
\hline
\end{tabular}

TEC = Total erythrocytes count; Hb = Hemoglobin; PCV = Packed cell volume; ESR = Erythrocyte Sedimentation Rate; TLC = Total leukocyte count; $\mathrm{SE}=$ Standard Error

$* *=$ Significant at 1 percent level $(\mathrm{p}<0.01) ; *$ Significant at 5 percent level $(\mathrm{p}<0.05)$ 
The live weight gain of goats in group A, group $\mathrm{B}$, group $\mathrm{C}$ recorded at ' 0 ' day and $28^{\text {th }}$ day and the percentage of improvement of body weight in kilogram were $2.04 \%, 0.96 \%$ and $6.40 \%$ respectively and in control group it was reduced by $0.00 \%$ (Table 3 ).

Table 3: Body weight $(\mathrm{Kg})$ gain/loss (comparative efficacy) of goat in various treatment days

\begin{tabular}{|c|c|c|c|c|c|c|}
\hline Groups & Treatment & $\begin{array}{l}\text { Pre- treatment } \\
\text { Day 0 } \\
\text { Body weight } \\
(\mathrm{kg})\end{array}$ & $\begin{array}{l}\text { Post-treatment } \\
\text { Day } 28 \\
\text { Body weight } \\
(\mathrm{kg})\end{array}$ & $\begin{array}{l}\% \\
\text { change }\end{array}$ & $\begin{array}{l}\text { Bodyweight } \\
\text { of individu- } \\
\text { al goat (kg) }\end{array}$ & $\begin{array}{l}\text { Mean } \\
(\%)\end{array}$ \\
\hline GA & Inj. Vermic ${ }^{\circledR}$ & $\begin{array}{l}14.38 \\
\pm \\
0.16\end{array}$ & $\begin{array}{l}14.68 \\
\pm \\
0.14 *\end{array}$ & 2.04 & +3.20 & +2.64 \\
\hline GB & Peraclear (®) & $\begin{array}{l}14.44 \\
\pm \\
0.14\end{array}$ & $\begin{array}{l}14.58 \\
\pm \\
0.18^{*}\end{array}$ & 0.96 & +2.80 & +2.46 \\
\hline GC & Almex- vet ${ }^{\circledR}$ & $\begin{array}{l}14.34 \\
\pm \\
0.09\end{array}$ & $\begin{array}{l}15.32 \\
\pm \\
0.40^{*}\end{array}$ & 6.40 & +3.60 & +3.04 \\
\hline GD & Control group & $\begin{array}{l}14.30 \\
\pm \\
0.05\end{array}$ & $\begin{array}{l}14.30 \\
\pm \\
0.03 *\end{array}$ & 0.00 & -1.60 & -1.35 \\
\hline
\end{tabular}

\section{Discussion}

Effects of various anthelmintics in same individual were different during parasitic infestations. It occurred due to the potency of different anthelmintic against gastrointestinal nematodiasis in goats. Islam et al. (1994) reported the 100\% efficacy of Ivermectin (pour on formulation) against gastrointestinal nematodes in cattle

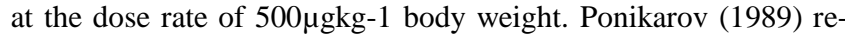
ported $100 \%$ efficacy of Ivomec-F (Ivermectin) at the dose rate of $1 \mathrm{mgkg}-1$ body weight when given as a subcutaneous injection against gastrointestinal nematodes. Shastri (1989) reported 97.5\% and $93.3 \%$ efficacy of Ivermectin against gastrointestinal nematodes in goats. Baggherwal et al. (1991) observed 100\% efficacy of Ivermectin against naturally acquired nematodiasis in goats with a single subcutaneous injection of $0.2 \mathrm{mgkg}-1$ body weight Mukherjee et al. (1994) reported 100\% efficacy of Ivermectin against all types of nematodes (Trichostrongylus spp, Strongylus spp, Trichuris spp and Nematodirus spp) in goat during a comparative study of three anthelmintics in Cashmere. Docastro and Cocuzza (1995) reported that ivermectin was highly effective at the dose rate of $200 \mu \mathrm{gkg}-1$ body weight against gastrointestinal nematodiasis in goats. Yadav et al. (1996) observed 99-100\% efficacy of Ivermectin against gastrointestinal nematodes in sheep and goat at the dose rate of $0.2 \mathrm{mgkg}-1$ body weight. Haq et al. (1984) reported that fenbendazole at the dose rate of $5 \mathrm{mgkg}-1$ body weight was $100 \%$ effective in goats naturally infected with various gastrointestinal nematodes. Rahmatulla et al. (1985) reported that fenbendazole at the dose rate of five mgkg- 1 body weight on goats was $100 \%$ effective after five days of treatment. Chand-Thakuri et al. (1994) found that fenbendazole at the dose rate of 10 mgkg-1 body weight was $100 \%, 100 \%$ and $33 \%$ effective against Trichostrongylus, Strongyloides and Trichuris respectively. The findings of the present study are more or less similar to the earlier researchers. Pomroy et al. (1988) reported that Almex-Vet either at the dose rate of $3.8 \mathrm{mgkg}-1$ repeated after 24 hours or as a singledose rate of $7.6 \mathrm{mgkg}-1$ body weight was $>99 \%$ effective in naturally infected Angora- X goats. Guha and Banerjee (1987) indicated that albendazole at the dose rate of $3.5 \mathrm{mgkg}-1$ body weights on goats showed $100 \%$ effect. Findings of the present study reasonably agreed with the findings of the above mentioned authors. TLC was decreased significantly $(\mathrm{p}<0.01)$ in all treated goats, and body weight increased significantly $(\mathrm{p}<0.05)$. These findings are in agreement with the other researchers. It was seen that TEC. Hb and PCV were increased and on the other hand. ESR and TLC values were decreased on post treatment days. The body weight was increased significantly $(\mathrm{p}<0.05)$ after Vermic, Peraclear and Almex-Vet treatment in group A, B and C respectively. These findings are more or less similar to the findings of Pandit et al. (2009). Thedford et al. (1990) studied the increased PCV of treated animals on days 28 and post treatment compared to treated animals on day ' 0 ' and control on day 28 . The mean value of $\mathrm{Hb}$, PCV and TEC were decreased and ESR, TLC values were increased in untreated naturally parasitized control group. This study indicated that Vermic (injectable Ivermectin) is a more effective drug against gastrointestinal nematodiasis in goats than that of Almex-Vet (Albendazole) and Peraclear (Fenbendazole).

\section{Conclusion}

The findings of the present study reveal that Haemonchus spp, Trichostrongylus spp, Cooperia spp, Oesophagostomum spp, Trichuris spp, Strongyloides spp and mixed infections are prevalent in Bangladesh. Ivermectin (Vermic, injectable formulation), Fenbendazole (Peraclear) and Albendazole (Almex-Vet) are effective in the reduction of EPG of gastrointestinal nematodes. This study indicated that Vermic (Ivermectin) is highly effective on egg count (EPG) and hematological parameters (TEC, Hb, PCV, ESR and TLC) in gastrointestinal nematodiasis in goats than that of Almex-Vet (Albendazole) and Peraclear (Fenbendazole) during the experiment. These three anthelmintics have wide therapeutic index and are capable of killing or inhibiting egg production of gastrointestinal nematodes. The findings of the present study may help the future researchers to explore the details pharmacokinetic and toxic effects, for wide therapeutic uses in Bangladesh for the treatment and control of parasitic infection in goat. Further studies are required to clarify the efficacy of the anthelmintics widely used in different agro ecologies, animal species and livestock management systems in Bangladesh. From these research findings, the veterinarian may use the specific anthelmintics for gastrointestinal nematodiasis in goats. Further studies on anthelmintics pharmacokinetic and toxicity would be helpful.

\section{Acknowledgements}

This study was supported by Department of Pharmacology and Toxicology Laboratory, Faculty of Veterinary and Animal Science, Sylhet Agricultural University, Sylhet for their technical support during this work. I also express my deep sense of gratitude and immense indebtedness to Professor Dr. Md. Siddiqul Islam, Department of Pharmacology and Toxicology, Faculty of Veterinary and Animal Science, Sylhet Agricultural University, Sylhet and Md. Nurul Islam, Livestock officer, Sylhet Government Goat Development Farm, Sylhet, Bangladesh for his scholastic guidance, constant inspiration, constructive criticism, and successful completion in the research work and preparation of this manuscript during this work.

\section{References}

[1] Baggherwal RK, Sisodia RS and Ghosal SB (1991). Efficacy of Ivermectin against naturally acquired nematodiasis in goats with special reference to its residual effect. Indian Vet. Med. J., 15:291-292.

[2] BBS (1998). Agricultural Census 1983-84. Bangladesh Bureau of Statistics, Ministry of Planning, Dhaka, Bangladesh.

[3] Beck AAH, Beck AA and Moreria WS (1971). Levamisole in sheep. Revistadocenteo da Ciecias Russis 1: 113-120.

[4] Chand-Thakuri K, RP Thakur and K Rai (1994). Comparative efficacy of Fenbendazole, Mebendazole and Krimos powder against natural infection of gastrointestinal nematodiasis of goats. Vet. ReviewKathmandu, 9:1-3.

[5] Coffin DL (1995). Manual of Veterinary Clinical Pathology. Third ed. Coinstock Publishing Associates. Inc. Ithaca New York, 116-157.

[6] Docastro M and Cocuzza U (1995). Efficacy of Ivermectin in reducing gastrointestinal nematode fecal egg counts in goats in Burundi. Preventive Veterinary Medicine, 23(3-4):173-178.

[7] DLS (2007). Government of Bangladesh, Directorate of Livestock Services, Dhaka, Bangladesh.

[8] Gordong HMcL and Whitlock HV (1939). A new technique for counting nematode eggs in sheep feces. JCSIR, Australia, 12:50-52. 
[9] Guha C and Banerjee AK (1987). Efficacy of four anthelmintics in the treatment of gastrointestinal nematodes of goats, a comparative assesment. Indian Vet. J., 64:335-337.

[10]Guha C, S Roy and Banerjee AK (1996). Efficacy of Albendazole (Axalgon) in the treatment of gastrointestinal nematodes in goats in West Bengal. Indian Vet. J., 63:1042-1044.

[11]Haq S and Shaikh H (1968). A survey of helminths parasitizing the gastrointestinal tract of goat and sheep in East Pakistan. Pak. J. Vet. Sci., 2:54-62.

[12]Haq SB, Verma B and Thakur DK (1984). Efficacy of Fenbendazole against mixed infections with gastrointestinal nematodiasis in goat. Indian Vet. J., 61:509-511.

[13] Howell SB, Burke JM, Miller JE, Terrill TH, Valencia E, Williams MJ, Williamson LH, Zajac AM and Kaplan RM (2008). Prevalence of anthelmintic resistance on sheep and goat farms in the Southeastern United States. J. Anim. Vet. Med. Assoc. 233(12): 1913-1919.

[14]Islam KS (1985). Present situation of livestock and Poultry Diseases in Bangladesh. In Jabbar, M. A. Bangladesh Poshushampad Unnayan - Neiti O Kowshal. BARC, Dhaka and ADC, N. Y. P., 48-128.

[15]Islam MI, Rafiq KM, Mostafa Alim M A and Haque M A (1994). Efficacy of Ivermectin against lice and ticks infestation in goats of Bangladesh. The Bangladesh Veterinarian, 15: 29-32.

[16]Jackson F and Coop RL (2000). The development of anthelmintic resistance to sheep nematodes (Supplement) Parasitology. 120(07): pp95-107.

[17]Kaplan RM, Burke JM, Terrill TH, Miller JE and Getz W R (2004). Validation of the FAMMACHA eye color chart for detecting clinical anaemia in sheep and goats on farms in the Southern United States. Veterinary Parasitology 123(1-2):105-120.

[18]Mukherjee R, R Laha, D Bhattacharya and Reena Mukherjee (1994) Comparative efficacy of tetramisole, Fenbendazole and Ivermectin against gastrointestinal nematode infection in Pashmina (Cashmere) goats. Indian J. Anim. Health, 33:125-127.

[19]Pandit S, Ghosh JD, Chinya A, Mandal M, Jas R and Moi S (2009) Evaluation of anthelmintic efficacy of Ivermectin, levamisole and albendazole against naturally occurring gastrointestinal nematodiasis in sheep. Journal of Veterinary Parasitological, 23(2): 971-973.

[20]Perry BD, Randolph TF, Mc Dermott JJ, Sones KR. and Thornton PK (2002). Investigating in an animal health research to alleviate poverty. International Livestock Research Institute, Nairobi, Kenya pp: 148.

[21]Pomroy WE, Gething MA and Charlexton WAG (1988). The efficacy of Albendazole against some gastrointestinal nematodes in goats. New Zealand Veterinary Journal 36(3):105-107.

[22]Ponikarov AV (1989). Efficacy of Ivomec-F injection in sheep. By Uleten-Vesesoyunogo-Instituta-Gelmintologi-im,-K-1-Kryabina, $52: 86$.

[23]Prodhan KB, Thakur DK and Sudham NA (1993). Hematobiochemical changes in goats with natural helmintic infection in Ranchi. J. Res. Agric. University. 3(1): 119-121.

[24]Rahmatulla PS, Rajasudharam RC, Suresh RV and Nagarujarn R (1985). Effect of Fenbendazole as anthelmintic of goats. Indian Vet. J., 52:993-995.

[25]Russel DF (1996). MSTAT Director. Crop and soil science department, Michigan state university, USA.

[26]Sahlu T, Dawson LJ, Gipson TA, Hart SP and Merkel RC (2009). ASAS Centennial paper: Impact of animal science research on United States goat production and prediction for the future. J. Anim. Sci. 87(1): p400-418.

[27]Sharma LK and Jagadish S (1991). Efficacy of levamisole administered through different routes against gastrointestinal nematodes in cross breed cattle. Indian vet. J. 68: 16-18.

[28] Snedecor GW and Cochran WG (1967). Statistical Methods. Fifth Edn. The lowa State Univ. Press, Ames lowa, U. S. A.

[29]Soulsby EJL (1986). Helminth, Arthropods and Protozoa of Domesticated animals, 7th edition. The ELBS and Bailiers, Tindle, Cassell, London, p-216,234,763-766.

[30]Shastri UV (1989). Efficacy of ivermectin against gastrointestinal nematodiasis infection in goat. Indian Vet. J., 66: 345-346.

[31]Thedford TR, Worman FD and Kelmogile KM (1990). Effects of Ivermectin on Packed Cell Volume of goats when used to treat lice infestation. ATIP working paper. WP-26, II-6pp.

[32] Thejeomoorthy P, Sundararama MN, Napolean RE and Gajendran K (1995). Comparative efficacy of Fenbendazole and Levamisole against nematode in calves. Cheiron. 24(5-6): 154-162.

[33] Vesconcelos OT, Costa AJ, Aranties GJ, Barbosa OF and paulillo AC (1995). Anthelmintics activity of pour on levamisole against gastrointestinal nematodes in goats. Revista Brasileira Parasitological Veterinaria. 4:95-98
[34]Waller PJ (2006). Sustainable nematode parasite control strategies for ruminant livestock by grazing management and biological control. Anim Feed Sci Techl. 126(3-4): 277-289.

[35]Williams JC and Broussared SD (1995). Comparative efficacy of levamisole, thiabendazole and fenbendazole against gastrointestinal nematodes. Veterinay parasitology, 58(1-2): 83-90.

[36] Yadav CL, Ghouri SK, Singh BP and Sharma MC (1996). Benzimidazole resistance in Haemonchus contortus of sheep and goats in Uttar Pradesh in India. J. Vet. Parasitology, 10:47-51. 